\title{
HBD-2 INTERACTIONS WITH ERYTHROCYTE MEMBRANES IN VITRO
}

\author{
M. V. MAKARENKO', D. O. SEMENIUK ${ }^{2}$, I. O. STARENKA ${ }^{2}$, A. P. POGRIBNA ${ }^{3}$, \\ I. V. SOKOL ${ }^{4}$, L. I. MARTINOVA ${ }^{1}$, D. O. GOVSIEIEV ${ }^{4}$ \\ ${ }^{1}$ Institute of Postgraduate Education, \\ Bogomolets National Medical University, Kyiv Ukraine; \\ ${ }^{2}$ ESC Institute of Biology and Medicine, \\ Taras Shevchenko National University of Kyiv, Ukraine; \\ 凶e-mail:dmyt.semenyuk@gmail.com; \\ ${ }^{3}$ Institute of Molecular Biology and Genetics, NAS of Ukraine, Kyiv; \\ ${ }^{4}$ Kyiv City Maternity Hospital No 5
}

Received: 24 September 2018; Accepted: 13 December 2018

HBD-2 - a member of $\beta$-defensin family of antimicrobial peptides - is known to permeabilize cell membranes of susceptible cells, but the mechanism of such interactions is poorly understood. In our study, we used a hemolytic model to explore the kinetic properties of HBD-2 interactions with membranes of human erythrocytes. We ran hemolytic assays with a wide range of both $\mathrm{HBD}-2$ and erythrocyte concentrations, as well as varying $\mathrm{pH}$ values, incubation times, and osmotic strengths; each in the presence or the absence of inhibitory substances such as proteins and salts. The results show that HBD-2 cell membrane permeabilization is both dose- and time-dependent (with plateau effect observed in each case), and inversely dependent on erythrocyte concentration. HBD-2 interactions with cell membranes highly depend on $\mathrm{pH}$ value and the presence of inhibitors but are not affected by tested osmotic strength range. Our findings suggest that interactions of HBD-2 with cell membranes are mainly electrostatic in nature and are limited by released cell content. We developed a speculative model of such interaction based on our results.

Ke y wo rds: human beta-defensin 2, hemolytic activity, membrane permeabilization.

A ntimicrobial peptides play an important role in innate immunity and are critical for defense of mucosal surfaces [1]. HBD-2, a member of $\beta$-defensin family of antimicrobial peptides, is a small cationic peptide that was first isolated from psoriatic skin lesion in 1997 [2]. A number of other tissues and organs also express HBD-2 [3]. Expression of HBD-2 is regulated by both infectious and inflammatory stimuli [4]. Many authors have observed that HBD-2 demonstrates antimicrobial activity against bacteria [5], fungi [5], and enveloped viruses [6]. Such antimicrobial properties of HBD-2 are based on its ability to bind with cell membranes and permeabilize them [7].
Despite the numerous studies conducted on the subject matter, the details of kinetics and mechanisms of HBD-2 interaction with cell membranes are poorly understood. The inhibitory properties of anionic proteins [8] and salts [1] suggest that HBD-2 binding to cell membranes is electrostatic in nature. The fact that artificial vesicles with higher negatively-charged lipid content bind more $\alpha$-defensin molecules [9] supports this hypothesis. There is also evidence suggesting that HBD-2 may undergo oligomerization to form membrane-spanning pores, but such findings are controversial $[10,11]$. We focused our research on the kinetic properties of HBD-2 interactions with cell membranes since we had not

(C) 2019 Makarenko M. V. et al. This is an open-access article distributed under the terms of the Creative Commons Attribution License, which permits unrestricted use, distribution, and reproduction in any medium, provided the original author and source are credited. 
found any research papers published on the subject matter. Our goal was to observe the way the HBD-2 hemolytic activity is affected by various factors and to use the data from our findings to propose a model of HBD-2 interactions with erythrocyte membranes.

In this study, we have used a hemolytic model to observe kinetic properties of HBD-2 interactions with membranes of human erythrocytes. We have also examined the effects of albumin, hemoglobin, and some salts on HBD-2 hemolytic activity.

\section{Matherials and Methods}

Production and purification of recHBD-2. HBD-2 was produced by recombinant $E$. coli Roset$\mathrm{ta}^{\mathrm{TM}}$ strain that was transformed by pGEX-2T-HBD-2 construct as previously described [12]. To produce fusion protein, $300 \mathrm{ml}$ of LB medium containing $50 \mu \mathrm{g} / \mathrm{ml}$ of ampicillin was inoculated with $1 \mathrm{ml}$ of overnight culture, and then cultivated at $37^{\circ} \mathrm{C}$ while being vigorously shaken until it reached the absorbance value of $A_{600}=0.6$. Afterwards, IPTG was added to reach the final concentration of $1 \mathrm{mM}$, and incubation continued with vigorous shaking applied for $5 \mathrm{~h}$ until the culture reached the absorbance value of $\mathrm{A}_{600}=1.0-1.5$. Cells were settled to form a sediment using a centrifuge at $3000 \mathrm{~g}$ for $15 \mathrm{~min}$ and resuspended in lysis buffer $(50 \mathrm{mM}$ Tris- $\mathrm{HCl}$ $\mathrm{pH}$ 8.0, $150 \mathrm{mM} \mathrm{NaCl}, 1 \%$ (v/v) Triton X-100, $2 \mathrm{mg} /$ $\mathrm{ml}$ lysozyme and $1 \mathrm{mM}$ PMSF). The cells were lysed by sonication of cell suspension with ultrasound disintegrator for 5 times, each lasting for $30 \mathrm{~s}$ and with a $30 \mathrm{~s}$ rest on the ice bath in between. Two sessions of sonication were performed with a 5 min break in between. Cell debris was separated into a sediment by centrifugation at $10000 \mathrm{~g}$ for $10 \mathrm{~min}$. Supernatant was applied on $2 \mathrm{ml}$ packed column of glutathioneagarose and incubated at RT while being shaken for $2 \mathrm{~h}$. The column was rinsed with $3 \mathrm{x}$ volumes of equilibration buffer $(50 \mathrm{mM}$ Tris- $\mathrm{HCl} \mathrm{pH} 8.0$, $150 \mathrm{mM} \mathrm{NaCl}$ ) and $1 \mathrm{x}$ volume of proteolytic buffer (50 mM Tris- $\mathrm{HCl} \mathrm{pH} 8.0,150 \mathrm{mM} \mathrm{NaCl}, 2.5 \mathrm{mM}$ $\mathrm{CaCl}_{2}$ ). Proteolysis of fused protein was performed in proteolytic buffer with $10 \mathrm{U}$ of thrombin per $1 \mathrm{mg}$ of fused protein at RT while being carefully shaken for $16 \mathrm{~h}$. The products of proteolysis were acidified by trifluoracetic acid (TFA), reaching the final concentration of $0.1 \%(\mathrm{v} / \mathrm{v})$, and then centrifuged at $10000 \mathrm{~g}$ for $10 \mathrm{~min}$. Supernatant was separated by reverse-phase chromatography on Sep-Pak C-18 syringe cartridges. $75 \%$ acetonitrile solution with $0.1 \%$ (v/v) TFA was applied to perform the HBD-2 elu- tion. Afterwards, the eluate was air-dried using the Speed-Vac concentrator and stored at $-20^{\circ} \mathrm{C}$.

Densitometrical analysis. Dry eluate was dissolved in sample buffer and separated by standard PAGE-SDS in 7-22\% PAG gradient. Separation was performed in Laemmli's buffer system under $20 \mathrm{~mA}$ per gel $\left(10^{*} 6 \mathrm{~cm}\right)$ current. After separation, gels were stained with Coomassie Brilliant Blue G-250 and analyzed using free software Image Studio Lite. Data was collected from Green and Blue channels. Background signal averaged between top and bottom regions of spots. Results were calculated in relation to the calibration curve that was received for bovine serum albumin (BSA).

Western-blot analysis. Instead of staining the gels, they were used for electroblot transfer to nitrocellulose membrane at RT and $30 \mathrm{~V}$ overnight. Nitrocellulose membrane was blocked by $10 \%(\mathrm{w} / \mathrm{v})$ dry milk solution in PBS-T for 90 min. Membrane was incubated with anti-HBD-2 antibody (\#SC20798, Santa Cruz Biotechnology) solution for $60 \mathrm{~min}$, rinsed off five times, and then incubated with secondary antibody (\#AP1320, MilliPore) solution for $60 \mathrm{~min}$ and rinsed off 5 times again. The results were visualized using ECL technique.

MALDI-TOF-MS (Matrix assisted laser desorption/ionization time of flight mass spectrometry). Dry eluate was dissolved in $0.1 \%(\mathrm{v} / \mathrm{v})$ TFA, reaching the final concentration of $1 \mathrm{mg} / \mathrm{ml}$, then mixed with an equal volume of ionization matrix ( $\alpha$-cyano-4hydroxycinnamic acid) and loaded onto a steel sample plate for drying. MALDI-TOF mass spectrometry assay was performed in positive linear mode ranging from 1000 to $7000 \mathrm{~m} / \mathrm{z}$.

Hemolytic assay. Blood received from healthy volunteers after venipuncture was added to $3.6 \%$ $(\mathrm{w} / \mathrm{v})$ sodium citrate solution in proportion 9:1. The resulting solution was carefully mixed by inverting the tube. Erythrocytes were triple washed in $270 \mathrm{mM}$ sucrose solution and counted manually. No visible hemolysis occurred. Afterwards, erythrocytes were diluted in various isotonic solutions, which either contained an inhibitory agent or not. Then each HBD-2 solution (in deionized water) was added to suspension and was carefully mixed afterwards. Samples containing equal volumes of either water or $5 \%(\mathrm{v} / \mathrm{v})$ Triton-X100 were considered as negative and positive controls, respectively. They were set for each probe. Suspensions were incubated at $37{ }^{\circ} \mathrm{C}$, each with a different incubation time, and separated by centrifuge at $400 \mathrm{~g}$ for $5 \mathrm{~min}$. In 
each case, the absorbance value of supernatant was measured four times at $545 \mathrm{~nm}$. Intensity of hemolysis was calculated using the following formula:

$$
H \%=\left(\left(A_{\text {sam }}-A_{\text {neg }}\right) /\left(A_{\text {pos }}-A_{\text {neg }}\right)\right) \times 100 \%,
$$

where $H \%$ - intensity of hemolysis in percent (referred to as the hemolytic activity), A-absorbance value (sam - of the sample; neg - of the negative control; pos - of the positive control).

Hemolytic assay conditions. We supposed that five major factors excluding temperature may impact HBD-2 hemolytic activity. Thus, we varied values for some of these factors while keeping others constant. The ranges for factors were the following: 0.005-4 $\mu \mathrm{M}$ of recHBD-2 concentration; $5-9 \mathrm{pH}$ value; 5-120 min of incubation time; 100-1600 million/ml of erythrocyte concentration; 240-300 mM of sucrose concentration, which was used to check the influence of osmotic strength. Standard conditions were $4 \mu \mathrm{M}$ recHBD-2, pH 7 or 8 (marked on each graph), $200 \mathrm{million} / \mathrm{ml}$ erythrocytes, $60 \mathrm{~min}$ of incubation, and $270 \mathrm{mM}$ sucrose concentration. We also checked the influence of some hemolysis inhibitors on the hemolytic activity of HBD-2, such as BSA $(0.1-2.5 \mathrm{mg} / \mathrm{ml})$, total erythrocyte soluble protein $(0.1-2.5 \mathrm{mg} / \mathrm{ml}$; more information below), sodium chloride $(15-150 \mathrm{mM})$, potassium chloride (15-150 $\mathrm{mM})$, calcium chloride $(0.1-2.5 \mathrm{mM})$, and magnesium chloride (0.1-2.5 mM).

Total erythrocyte soluble protein (TESP) preparation). $2 \mathrm{x}$ volumes of $50 \%$ suspension of washed erythrocytes were added to $1 \mathrm{x}$ volume of $270 \mathrm{mM}$ sucrose solution. Erythrocytes were lysed by sonication of cell suspension with ultrasound disintegrator once for $30 \mathrm{~s}$, and then rested on an ice bath. Cell debris was separated using a centrifuge at $10000 \mathrm{~g}$ for $10 \mathrm{~min}$. Protein concentration in supernatant was measured by Greenberg method [13].

Statistical method. Standard statistical methods were used to process data, which was presented in terms of a mean and standard deviation. Differences between groups were calculated using U-test, with statistical significance of $P<0.05$.

\section{Results and Discussion}

Characterization of recHBD-2. Recombinant HBD-2 produced by E. coli-based expression system was isolated and checked for purity and quantity by densitometrical analysis (Fig. 1, A). $1.07 \pm 0.08 \mu \mathrm{g}$ of HBD-2 with purity of $70.5 \pm 6.2 \%(n=6)$ was obtained from $1 \mathrm{ml}$ of cell suspension. Mass-spectral analysis of recHBD-2 identified a major peptide peak at $\mathrm{m} / \mathrm{z} 4475.7$ (Fig. 1, C). This value is in good agreement with calculated mass, which is slightly higher comparing to the native form because of two additional GST-tag derived amino acids on N-terminus. Western-blot with primary antibody against native HBD-2 shows that purified recHBD-2 displays the same linear antigen structure as native form (Fig. 1, $B)$. These observations suggests that primary structures of recHBD-2 and native HBD-2 are the same.

Kinetics of recHBD-2-erythrocyte interactions. Hemolytic assay shows that recHBD-2 possess hemolytic activity in concentrations from 0.25 to $4 \mu \mathrm{M}$ (Fig. 2, A). Hemolytic activity is dosedependent and tends to reach a plateau at $18 \%$ of hemolysis. Therefore, we've found the existence of saturation effect at $4 \mu \mathrm{M}$ HBD-2 concentration. Similar pattern of hemolytic activity for HBD-3 was observed by Harder et al. [14], but they failed to reach a plateau. Wimley et al. [9] obtained exactly the same results for artificial vesicle lysis by HNP-2, but plateau was reached at a higher percentage of lysis. Based on this evidence, we conclude that dosedependent pattern with plateau effect may be a common property of defensins in general rather than one specific to HBD-2.

We observed that medium $\mathrm{pH}$ value strongly impact hemolytic activity. The maximum activity of around $80 \%$ was identified at pH 8.0 (Fig. 2, B). It supports the hypothesis of electrostatic nature of this interaction because the $\mathrm{pH}$ value of 8.0 is between the constant of dissociation value of membrane lipid phosphoric heads $\left(\mathrm{pK}_{2}=7\right)$ and isoelectric point of HBD-2 ( $\mathrm{pI}=9.3$ ). According to Coulomb's law, the electrostatic interactions between cell membranes and HBD-2 are at their maximum at this $\mathrm{pH}$ value. We failed to find a study that links any HBD-2 or beta-defensin activity with $\mathrm{pH}$ value, but Nakayama et al. [15] have found a reduction of antimicrobial activity of surface liquids in epithelial cells culture (that may contain HBD-2) as $\mathrm{pH}$ decreased. To increase assay sensitivity in some of our further observations, we used $\mathrm{pH} 8.0$ as well as 7.0.

Hemolytic activity also depends on the incubation time. After even 5 min of incubation, strong hemolysis $(29.3 \%)$ occurs, but hemolysis rates tend to decrease and reach a plateau after $60 \mathrm{~min}$ (Fig. 2, C). Similar pattern was observed in Wimley's study [9]. Plateau effect depends both on HBD-2 concentration and incubation time, which leads us to conclude that as the reaction intensifies, some kind of inhibitors 


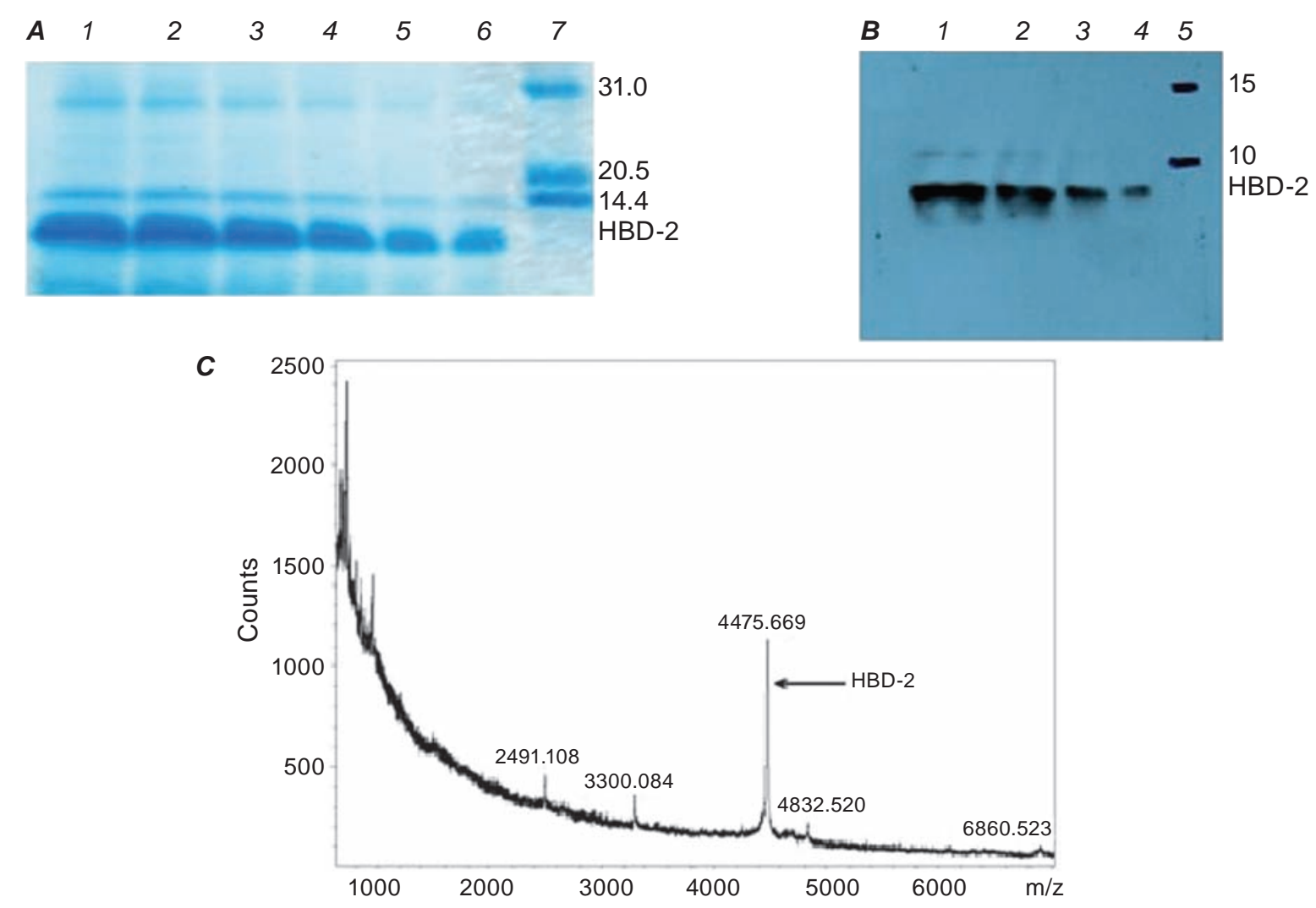

Fig. 1. Characterization of recHBD-2. A - Electrophoregram of purified recHBD-2: $1-10 \mu g, 2-8 \mu \mathrm{g}, 3-$ $6 \mu \mathrm{g}, 4-4 \mu \mathrm{g}, 5-2 \mu \mathrm{g}, 6-1 \mu \mathrm{g}, 7$ - LMW protein marker; $\boldsymbol{B}$ - Blotogram of purified recHBD-2: 1 - $750 \mathrm{ng}, 2-$ $500 \mathrm{ng}, 3-250 \mathrm{ng}, 4-100 \mathrm{ng}, 5$ - Spectra ${ }^{T M}$ protein marker; $\boldsymbol{C}$-MALDI-TOF spectrum of purified recHBD-2

may start to appear in the solution, resulting in the plateau effect observed.

Hemolytic activity is inversely dependent on erythrocyte concentration. A 4-time increase of erythrocyte concentration reduces the hemolytic activity in half (Fig. 2, D). We did not expect such results because if hemolysis is a simple reaction that involves two components (HBD-2 and erythrocytes), then when the concentration of one of the components increases, the reaction rate should increase instead of decreasing, as observed in our study. Therefore, we conclude that hemolysis depends on several factors rather than just concentrations of reagent. The simplest example of such factors is the ratio of HBD-2 to erythrocyte concentrations.

Hemolysis inhibition by proteins. Anionic proteins can inhibit antimicrobial activity of HBD-2 [8], so we hypothesized that some of anionic erythrocyte proteins, mainly hemoglobin, may inhibit hemolytic activity of recHBD-2, thus causing plateau effects and decreasing hemolytic activity as the erythrocyte concentration increases. To assess this hypothesis, we performed the hemolytic assay in standard con- ditions with addition of different quantities of TESP (total erythrocyte soluble protein) and BSA to compare their effects. The concentrations of proteins varied from 0.1 to $2.5 \mathrm{mg} / \mathrm{ml}$. The assay showed that both BSA and TESP strongly inhibit hemolytic activity, with the complete inhibition reached at the concentration of $2.5 \mathrm{mg} / \mathrm{ml}$ (Fig. 3, A). However, TESP inhibits hemolytic activity slightly less compared to BSA. Based on the fact that HBD-2 is cationic peptide, we suppose that its electrostatic binding to anionic proteins leads to weakening of HBD-2 interactions with erythrocyte membranes because of the neutralization of total HBD-2 charge. We also expect that proteins with higher negative charge will inhibit hemolytic activity of HBD-2 stronger. Our results support this assumption, since BSA has stronger charge at $\mathrm{pH} 8.0$ than that of hemoglobin (which is the main component of TESP) because its isoelectric point is lower (4 compared to 7). Hence, our observation confirms that interaction of HBD-2 with erythrocyte membranes are electrostatic in nature. We furthermore conclude that the protein release from erythrocytes during hemolysis 

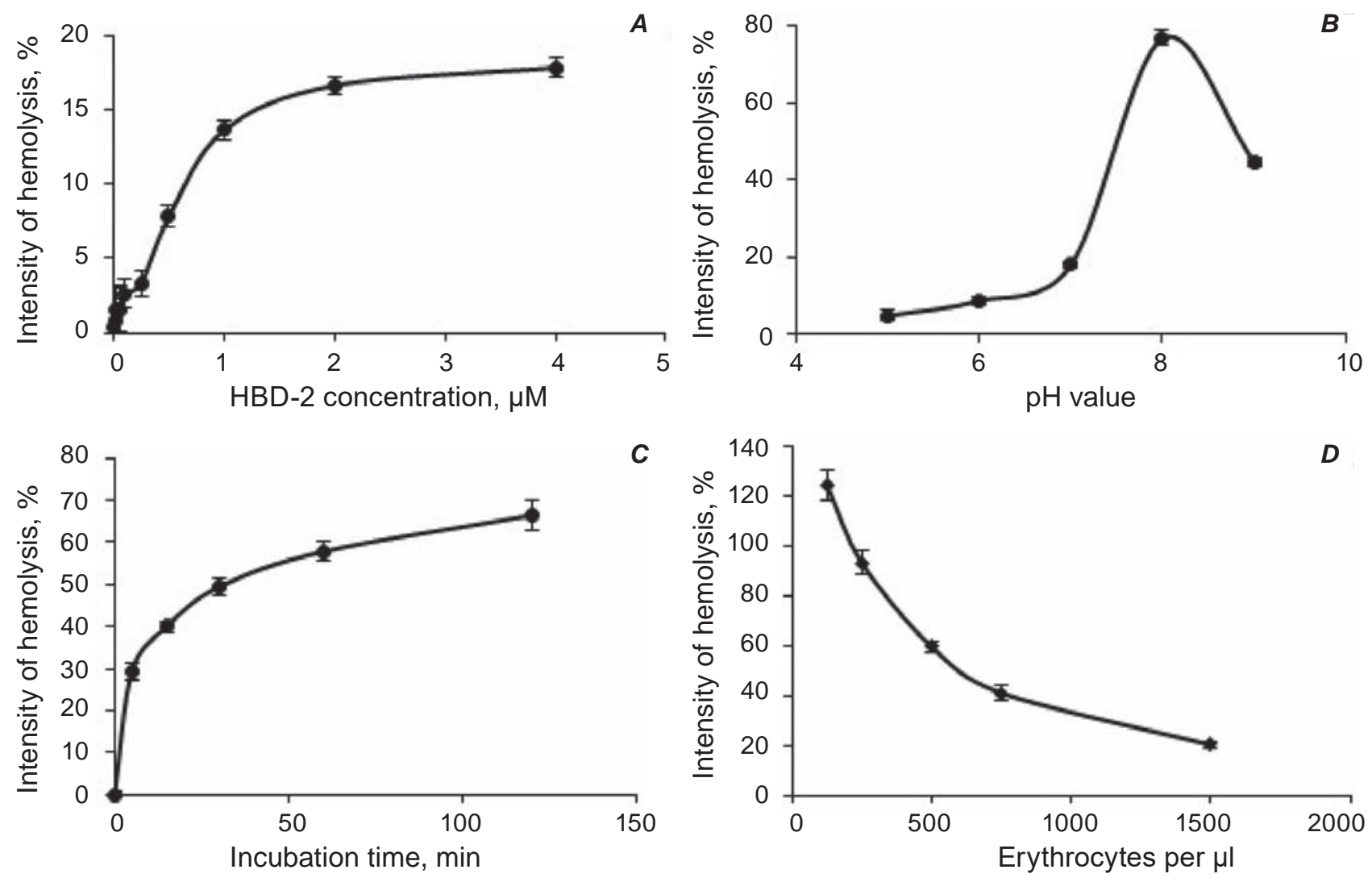

Fig. 2. Hemolytic activity of HBD-2 under different test conditions (see text). Hemolytic assay was performed in $270 \mathrm{mM}$ sucrose solution with $\mathrm{pH}$ value $7(\mathbf{A}), 8(\boldsymbol{C}, \boldsymbol{D})$ or a wide range of $\mathrm{pH}(\mathbf{B})$ for $60 \mathrm{~min}$ (except $\boldsymbol{C}$, where we tested different incubation time). $H B D-2$ concentration was $4 \mu M$ in all cases except $\mathbf{A}$ (where we tested different HBD-2 concentration) and erythrocyte concentration was 200 million per $\mathrm{ml}$ in all cases except for $\boldsymbol{D}$ (where we tested their different concentration). Intensity of hemolysis was measured relatively to that caused by 5\% Triton-X100. Error bars indicate standard deviation of the means of four measurements

inhibits hemolytic activity of HBD-2, thus making this reaction self-limited. This explains both why the increase of either the recHBD-2 concentration or the incubation time did not increase the overall percentage of hemolysis and why erythrocytes themselves inhibit the hemolytic activity of HBD-2.

Hemolysis inhibition by salts. HBD-2 demonstrates poor antimicrobial activity in the presence of salts [1]. Therefore, to find out whether this effect relies on the changes in osmotic strength or the physical properties of salts, we performed a hemolytic assay without any salts but in presence of different concentrations of sucrose (which created solutions with different osmotic strengths). We have not observed any difference in hemolytic activity of HBD-2, except for a small drop in hemolytic activity in $300 \mathrm{mM}$ sucrose solution (Fig. 3, B). Therefore, we conclude that osmotic strength itself does not impact the hemolytic activity of HBD-2.
To prove the second assumption, a hemolytic assay was performed in isotonic sucrose solution that contained sodium chloride and potassium chloride in concentrations from 15 to $150 \mathrm{mM}$, and magnesium chloride and calcium chloride in concentrations from 0.1 to $2.5 \mathrm{mM}$. If our assumption were true, we had to find out differences in inhibition of hemolytic activity caused by different physical properties of cations present in salts. This assay shows that all tested cations strongly inhibit hemolytic activity of HBD-2 (Fig. 3, C, D). Minimal salt concentrations required for a statistically significant decrease of hemolytic activity were the following: $0.1 \mathrm{mM}$ of magnesium chloride; $0.5 \mathrm{mM}$ of calcium chloride; $15 \mathrm{mM}$ of sodium chloride and potassium chloride (although the inhibition by sodium chloride was more pronounced). The first observation based on these results is that double charged magnesium and calcium cations are much more potent than single charged 

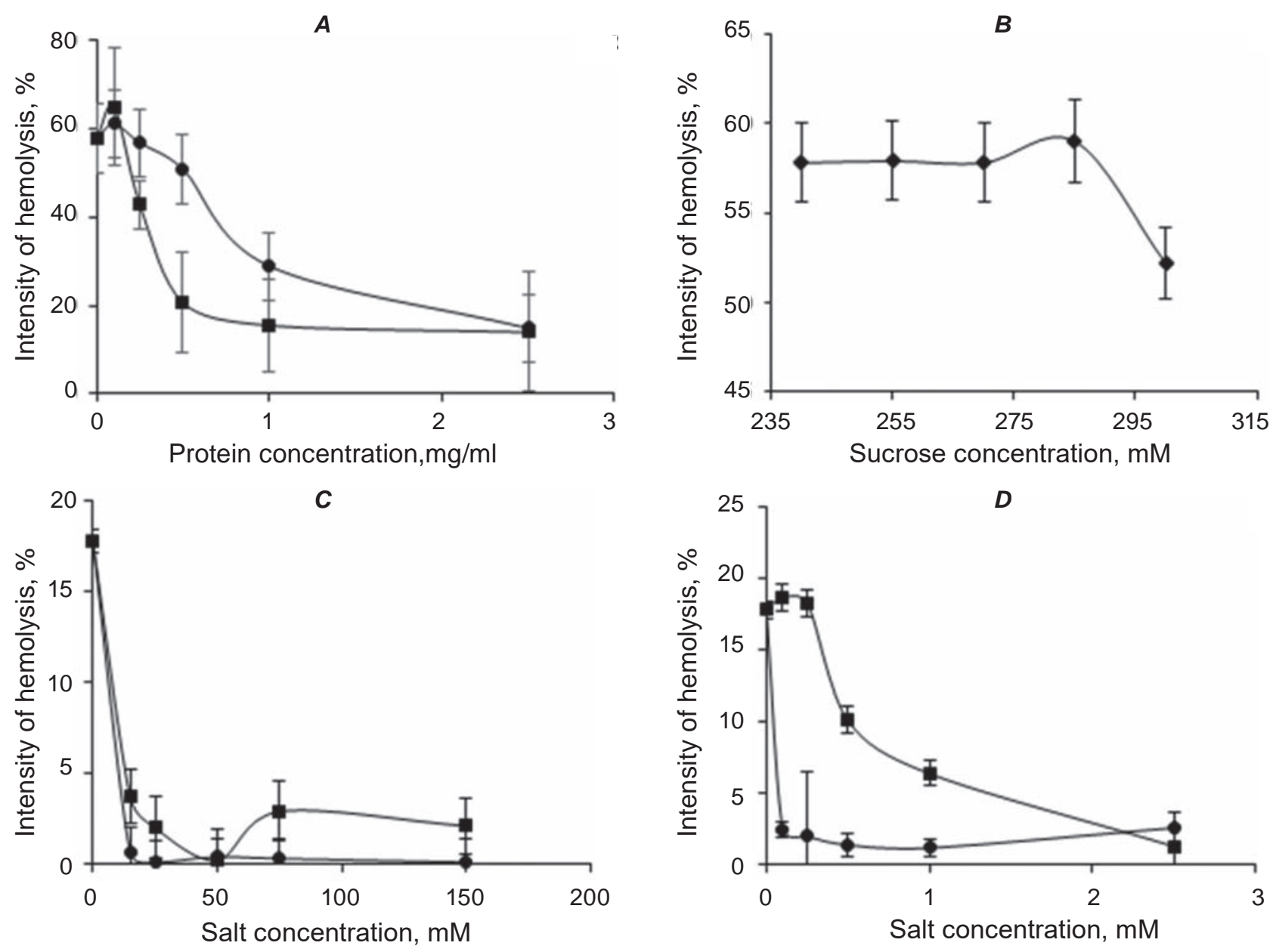

Fig. 3. Hemolytic activity inhibition by proteins, salts and sucrose. Hemolytic assay was performed in (A) $270 \mathrm{mM}$ sucrose solution with the addition of 0.1-2.5 $\mathrm{mg} / \mathrm{ml} \mathrm{BSA}$ (bovine serum albumin (অ)) or TESP (total erythrocyte soluble protein (•)); (B) 240-300 mM sucrose solution; (C) isotonic sucrose solution with addition

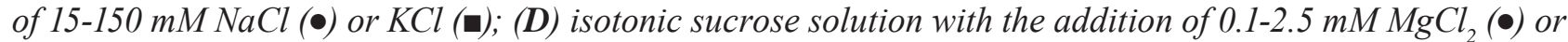
$\mathrm{CaCl}_{2}(\boldsymbol{\square})$ for 60 min and $\mathrm{pH}$ value $8(\boldsymbol{A}, \boldsymbol{B})$ or $7(\boldsymbol{C}, \boldsymbol{D})$. HBD-2 and erythrocyte concentrations were $4 \mu M$ and 200 million per $\mathrm{ml}$, respectively. Intensity of hemolysis was measured relatively to the hemolysis caused by the 5\% Triton-X100. Error bars indicate standard deviation of the means of four measurements

sodium and potassium ones. The second observation is that cations with smaller atomic radii (sodium and magnesium) are more potent in inhibition than those with bigger atomic radii (potassium and calcium). These findings, in turn, support the hypothesis of the electrostatic nature of interactions of HBD-2 with cell membranes because double charged cations bind to membrane stronger, and thus inhibit HBD-2 binding to membrane more effectively. Smaller cations possess slightly higher surface charge density, thus binding of HBD-2 more effectively than bigger cations. As we can see, the strongest inhibitor of hemolytic activity and the smallest cation is hydrogen, which inhibits HBD-2 activity in micromolar concentrations ( $\mathrm{pH} 7$ and below). Our obser- vations are partly confirmed by the study of Tomita et al [16] that has found distinct impact of single and double charged ions on HBD-2 antimicrobial activity but failed to find differences in the impact of smaller and bigger cations.

Speculative model of HBD-2-membrane interaction. Based on the set of performed hemolytic assays, we make several hypotheses about HBD-2 interactions with cell membranes. Such hypotheses are weak in evidence now but can be explored in further research. First of all, we conclude that these interactions are mainly electrostatic in nature. As depicted in Fig. $2(B)$ and Fig. 3 ( $A, C$ and $D$ ), the higher charge or the higher surface charge density a substance has, the stronger this substance inhibit the 
HBD-2 interaction with erythrocyte membranes. It is remarkable that these interactions are inhibited by charged molecules of any kind. Negatively charged substances bind HBD-2 and positively charged substances bind to cell membrane, but both make HBD-2 interactions with cell membrane weaker. Since the interaction of HBD-2 with membranes of living cells induces leakage of charged molecules (such as hemoglobin), HBD-2 activity will always be inhibited by these factors. Therefore, we consider that interaction of HBD-2 with cell membranes of living cell is self-limited.

As it was shown above, interactions of HBD-2 with cell membranes depend on the ratio of HBD-2 to erythrocyte concentrations. However, the decrease in hemolytic activity in high osmotic strength medium, which may be due to the decrease of available binding sites on membranes caused by membrane crashing, leads us to conclude that the ratio of HBD-2 concentration to total membrane surface available is critical for such interactions to occur.

To explain HBD-2 and erythrocytes concentrations impact on hemolytic activity, we hypothesized that binding of HBD-2 to cell membrane is normally distributed around HBD-2 concentration to total membrane surface ratio point and all erythrocytes that have HBD-2 concentration on their surface above some threshold level become disrupted. As HBD-2 concentration increases, more and more erythrocytes reach that threshold level, causing stronger hemolysis to occur. Assuming our hypothesis is correct, we expect that the graph of the dependence of hemolysis on HBD-2 concentration behaves similarly to that of normal distribution in its integral form, which, based on the properties of normal distribution, explains the linear dose-dependency shown in Fig. 2 (A).

The increase of erythrocyte concentration leads to a decrease in the percentage of erythrocytes that become disrupted, but the count of disrupted erythrocytes is partly compensated by the increase of the overall erythrocyte concentration. It is remarkable that the count of disrupted erythrocytes may not be constant. In some hemolytic assays we registered the decrease of the count of disrupted erythrocytes with the increase of erythrocyte concentration (data not shown). Thus, the inverse dependency depicted in Fig. $2(D)$ is better explained by the shift in the ratio of HBD-2 to erythrocyte concentrations that is masked by leakage of inhibitors from disrupted erythrocytes rather than by only the mere HBD-2 inhibition that has not explain how this effect may occur.

A threshold level may be a function dependent on different factors, mainly $\mathrm{pH}$ value and inhibitor presence, but based on our experiment with TESP, we suggest that a threshold level may be an internal function as well. If concentration of inhibitors (e.g. hemoglobin) determines the threshold level, then the optical density of supernatant after hemolytic assay must be constant regardless of TESP presence. However, that is not true based on our findings. Therefore, we conclude that the threshold level is the critical concentration of HBD-2 on cell membranes required for HBD-2 oligomerization during membrane-spanning pore formation.

We believe that our findings can explain some details of interactions of HBD-2 and other defensins with cell membranes.

Our findings suggest that interactions of HBD-2 with cell membranes are mainly electrostatic in nature and are self-limited by released cell content. Based on our results, we developed and presented a speculative model of such interactions.

Acknowledgments. We would like to thank Dr. Peter Pogribnyy for conceptual contribution in research and Taras Gromovoy for the use of the mass-spectrometer.

Conflict of interest. Authors have completed the Unified Conflicts of Interest form at http:// ukrbiochemjournal.org/wp-content/uploads/2018/12/ coi_disclosure.pdf and declare no conflict of interest. 


\section{ВЗАСМОДІї НВD-2 3 МЕМБРАНАМИ ЕРИТРОЦИТІВ IN VITRO}

М. В. Макаренко I. О. Старенька², А. П. Погрібна I. В. Сокол ${ }^{4}$, Л. І. Мартинова ${ }^{1}$, Д. О. Говсєєв ${ }^{4}$

${ }^{1}$ Інститут післядипломної освіти Національного медичного університету імені О. О. Богомольця, Київ, Україна; ${ }^{2}$ ННЦ «Інститут біології та медицини», Київський національний університет імені Тараса Шевченка, Україна; 凶e-mail: dmyt.semenyuk@gmail.com; ${ }^{3}$ Інститут молекулярної біології і генетики НАН України, Київ; ${ }^{4}$ Київський міський пологовий будинок №5, Україна

HBD-2 - антимікробний пептид родини $\beta$-дефенсинів - відомий здатністю пермеабілізувати мембрани чутливих клітин, але механізм такої взаємодії мало вивчений. У дослідженні ми використали гемолітичну модель для того, щоб дослідити кінетичні властивості взаємодії HBD-2 із мембранами еритроцитів людини. Для цього проводили гемолітичний тест iз широким діапазоном концентрації HBD-2 та еритроцитів. Крім того, варіювали значення $\mathrm{pH}$, тривалість інкубації та осмотичну силу 3 додаванням інгібувальних речовин, таких як протеїни та солі. Показано, що пермеабілізація мембран прямо пропорційна як концентрації HBD-2, так і тривалості інкубації (з ефектом плато у кожному випадку) і обернено пропорційна концентрації еритроцитів. Взаємодія HBD-2 iз мембранами клітин також сильно залежала від значення $\mathrm{pH}$ та присутності інгібіторів, але не залежала від осмотичної сили розчину. Таким чином, взаємодія HBD-2 із мембранами клітин $\epsilon$, головним чином, електростатичною за своєю природою та обмежена вмістом клітини, що вивільняється в процесі пермеабілізації. На основі цих результатів розроблено спекулятивну модель зазначеної взаємодії.

К л ю ч о в і с лов а: $\beta$-дефенсин 2 людини, гемолітична активність, пермеабілізація мембран.

\section{References}

1. Bals R, Wang X, Wu Z, Freeman T, Bafna V, Zasloff M, Wilson JM. Human beta-defensin 2 is a salt-sensitive peptide antibiotic expressed in human lung. J Clin Invest. 1998; 102(5): 874880.

2. Harder J, Bartels J, Christophers E, Schröder JM. A peptide antibiotic from human skin. Nature. 1997; 387(6636): 861.

3. Schröder JM, Harder J. Human beta-defensin-2. Int J Biochem Cell Biol. 1999; 31(6): 645-651.

4. Sørensen OE, Thapa DR, Rosenthal A, Liu L, Roberts AA, Ganz T. Differential regulation of beta-defensin expression in human skin by microbial stimuli. J Immunol. 2005; 174(8): 4870-4879.

5. Joly S, Maze C, McCray PB Jr, Guthmiller JM. Human beta-defensins 2 and 3 demonstrate strain-selective activity against oral microorganisms. J Clin Microbiol. 2004; 42(3): 1024-1029.

6. Gwyer Findlay E, Currie SM, Davidson DJ. Cationic host defence peptides: potential as antiviral therapeutics. BioDrugs. 2013; 27(5): 479-493.

7. Nguyen LT, Haney EF, Vogel HJ. The expanding scope of antimicrobial peptide structures and their modes of action. Trends Biotechnol. 2011; 29(9): 464-472.

8. Huang LC, Redfern RL, Narayanan S, Reins RY, McDermott AM. In vitro activity of human betadefensin 2 against Pseudomonas aeruginosa in the presence of tear fluid. Antimicrob Agents Chemother. 2007; 51(11): 3853-3860.

9. Wimley WC, Selsted ME, White SH. Interactions between human defensins and lipid bilayers: evidence for formation of multimeric pores. Protein Sci. 1994; 3(9): 1362-1373.

10. Hoover DM, Rajashankar KR, Blumenthal R, Puri A, Oppenheim JJ, Chertov O, Lubkowski J. The structure of human beta-defensin-2 shows evidence of higher order oligomerization. $J$ Biol Chem. 2000; 275(42): 32911-32918. 
11. Bauer F, Schweimer K, Klüver E, ConejoGarcia JR, Forssmann WG, Rösch P, Adermann K, Sticht H. Structure determination of human and murine beta-defensins reveals structural conservation in the absence of significant sequence similarity. Protein Sci. 2001; 10(12): 2470-2479.

12. Pogribnoy PV, Lisovskiy IL, Markeeva NV, Shnitsar VM, Zinchenko II, Soldatkina MA. Production of recombinant of hbd-2-human antimicrobial peptide expressed in cervical and vulval cancer. Exp Oncol. 2003; 25(1): 36-39.

13. Greenberg CS, Craddock PR. Rapid singlestep membrane protein assay. Clin Chem. 1982; 28(7): 1725-1726.
14. Harder J, Bartels J, Christophers E, Schroder JM. Isolation and characterization of human beta -defensin-3, a novel human inducible peptide antibiotic. J Biol Chem. 2001; 276(8): 5707-5713.

15. Nakayama K, Jia YX, Hirai H, Shinkawa M, Yamaya M, Sekizawa K, Sasaki H. Acid stimulation reduces bactericidal activity of surface liquid in cultured human airway epithelial cells. Am J Respir Cell Mol Biol. 2002; 26(1): 105-113.

16. Tomita $T$, Hitomi $S$, Nagase $T$, Matsui $H$, Matsuse T, Kimura S, Ouchi Y. Effect of ions on antibacterial activity of human beta defensin 2 . Microbiol Immunol. 2000; 44(9): 749-754. 